\title{
Ammonite stratigraphy of a Toarcian (Lower Jurassic) section on Nagy-Pisznice Hill (Gerecse Mts, Hungary)
}

\author{
András Galácz \\ Department of Paleontology \\ Eötvös Loránd University, Budapest \\ Barnabás Géczy \\ Department of Paleontology \\ Eötvös Loránd University, Budapest
}

\author{
Géza Császár \\ Department of Regional Geology \\ Eötvös Loránd University, Budapest \\ Zoltán Kovács \\ Department of Pedagogy \\ Liszt Ferenc University, Budapest
}

In the Jurassic rocks exposed in a small abandoned quarry on the northwestern edge of NagyPisznice Hill in the Gerecse Mts, fairly well preserved parts of a crocodile skeleton was found in 1996. The bed which yielded the skeletal remains is the uppermost layer of the Kisgerecse Marl Formation exposed here and was determined as belonging to the Upper Toarcian Grammoceras thouarsense Zone. The beds of the sequence above and below were carefully sampled in the late 1990s, and the encountered ammonites were evaluated biostratigraphically. As a result, the Lower Toarcian Harpoceras serpentinum Zone, the Middle Toarcian Hildoceras bifrons and Merlaites gradatus Zones, and the Upper Toarcian Grammoceras thouarsense and Geczyceras speciosum Zones were identified. Within most of these zones the subzones and even the faunal horizons were successfully recognized. The lowermost beds above the underlying Pliensbachian red limestone did not yield any fossils; thus the lowermost Toarcian Dactylioceras tenuicostatum Zone could not be documented. The highest Toarcian ammonite zones also remained unidentified, because the beds of the Tölgyhát Limestone above were not sampled all the way up. This paper presents the lithostratigraphic and biostratigraphic details of the sequence, and the paleontological descriptions of the most important ammonites.

Key words: Gerecse Mountains, Nagy-Pisznice Hill, Toarcian, Ammonoidea, biostratigraphy

\section{Introduction}

In summer of 1996 a minor sensation was created by the announcement that private collectors had unearthed a skeleton of a vertebrate - soon identified as that of a marine crocodile - from the Jurassic beds of the Gerecse Mts. One of the present authors, Géza Császár, then of the Hungarian Geological Institute,

\footnotetext{
Address: $\quad$ A. Galácz, G. Császár, B. Géczy: H-1117 Budapest, Pázmány Péter sétány 1/C, Hungary Corresponding author e-mail: galacz@ludens.elte.hu Z. Kovács: H-1076 Budapest, Liszt Ferenc tér 8, Hungary

Received: February 23, 2011; accepted: March 10, 2011
} 
realized the importance of the find, and suggested a detailed investigation and bed-by-bed sampling of the sequence immediately above and beneath the skeleton-bearing bed.

The initial steps of the sampling work were carried out in November 1997 by Zoltán Sirányi, one of the collectors who discovered the vertebrate remains. In the spring of the following year Attila Fitos, another collector, joined Zoltán Sirányi. Up to the end of the year they collected 21 fossils from the beds. In 1998 Z. Sirányi collected ammonites from a further 15 beds; thereafter Géza Császár and András Galácz, with occasional help from István Szente and István Főzy, completed the collection. The beds sampled by Z. Sirányi are those with numbers 1 to 36; the ones sampled later (those of G. Császár and A. Galácz) are numbered from 100 to 128. [There was a deliberate overlap made for the lowermost (36) of the former and the uppermost (100) bed of the later sampling, to avoid an arbitrary hiatus.] The ammonites and the samples for micropaleontological studies went to the Department of Paleontology of the Eötvös L. University. The limestone bed yielding the crocodile skeleton was initially assigned to the upper part of the Toarcian.

Recently detailed work has begun to clarify the taxonomy and systematic position of the crocodile skeleton now identified as Steneosaurus sp. (see Ôsi et al. 2010). Being a unique find, the determination of its stratigraphic position, as close as possible, could be also of value. Barnabás Géczy and Zoltán Kovács determined the collected ammonites and worked out the detailed ammonite stratigraphy of the section. Regarding the appearance of some rare forms, and the fact that the collected material enabled subdivision down to subzonal and even to faunal horizon level, it appeared justified to present a detailed report on the results.

\section{Previous studies on the Toarcian rocks of Nagy-Pisznice Hill}

Despite the excellent exposures (i.e. large quarries) and the centuries-old quarrying activity on Nagy-Pisznice Hill, surprisingly few geologic studies were made around this area. The first to mention Jurassic rocks in the closer area was Hantken (1872); later the Gerecse studies of Staff (1906) also included a discussion of the Jurassic formations. He provided stratigraphic descriptions of the Liassic and lower Middle Jurassic of Kis-Gerecse and the Pisznice Hills, evaluating the faunas together. It is clear from the definitions in his Table I that the sequence of "more clayey sediments of considerable thickness", where "more calcareous, harder beds alternate with more clayey, crumbly layers" (Staff 1906, p. 171) refers to the Lower, Middle and Upper Toarcian carbonates. It is worth mentioning that he recognized the dominance of phylloceratids among the ammonite fauna, since he reported that $54 \%$ of the Liassic and Middle Jurassic assemblages are represented by these forms. Prinz (1906a, b) described some Frechiella and Dumortieria specimens from the Toarcian material previously collected by Hantken from Nagy-Pisznice Hill. 
Liffa (1909, p. 153) also mentioned the Upper Liassic red limestone on the southern slope of Nagy-Pisznice Hill. Kulcsár, in his first Gerecse paper (1913) listed Nagy-Pisznice Hill as one of the localities of the Upper Liassic clayey, dark red limestone. In his subsequent paper in the following year (1914) he mainly dealt with the Middle Liassic of Tölgyhát Quarry, briefly mentioning the Upper Liassic formations.

Gyula (Julius) Vigh, who undertook general studies of the Jurassic of the Gerecse Mts (see Vigh 1925), devoted a separate paper to the Triassic and Jurassic of Nagy-Pisznice Hill (Vigh 1940). Unfortunately the quarries which served as the basis for his studies and descriptions are all abandoned and almost impossible to identify now; nevertheless, his stratigraphic conclusions are mostly valid even today. He assigned the lower part of the Upper Liassic red, clayey, nodular limestone into the Hildoceras bifrons Zone, the upper part into the 'radians-zone', and he distinguished the two levels by the upward decreasing clay content. In a previous paper on Paroniceras (Vigh 1927) he reported a specimen named as "Paroniceras sternale Buch var. (forma umbra Renz)" from the Middle Toarcian "clayey, dark red, nodular beds" of Nagy-Pisznice Hill. The formations in the Crocodile section, and the rocks above and below, show the same lithologic features and thickness as those described by Vigh in the other parts of NagyPisznice Hill. Gusztáv Vigh (1969) mentioned Nagy-Pisznice Hill as the place where the Toarcian clayey, nodular limestone occurs in its greatest thickness, i.e. 2.5-3 m.

In the 1970s the Geological Institute of Hungary, under the guidance of director J. Konda, carried out a detailed collection of the Middle and Lower Jurassic rocks in the large quarry of Nagy-Pisznice Hill. The sequence was described by Konda (1985). He recorded the $3.7 \mathrm{~m}$-thick Kisgerecse Marl between the ca. $9 \mathrm{~m}$-thick Middle Liassic limestone below and the $7 \mathrm{~m}$-thick Tölgyhát Limestone above. He distinguished three lithologically different parts within the Kisgerecse Marl, just as in the type section on nearby Kis-Gerecse Hill (Konda 1986). The partly re-interpreted section of the large Nagy-Pisznice quarry was presented by Császár et al. (1998, fig. 8).

The ammonites of the Toarcian beds in the large quarry of Nagy-Pisznice Hill were studied by Géczy (1984). In a subsequent short summary (in Géczy and Szente 2006) he mentioned that in the $8.4 \mathrm{~m}$-thick Toarcian sequence, comprising 74 numbered beds, all Toarcian zones except the Dactylioceras tenuicostatum Zone were able to be identified. He described a rich ammonite fauna from the middle Toarcian Hildoceras bifrons and Gradata Zones (fig. 5 in Géczy and Szente 2006). Kovács, in his papers on the Hammatoceratidae and Paroniceratidae of the Gerecse Mts (2009, 2010, respectively), also reported middle and upper Toarcian ammonites of these families from Pisznice Hill. 


\section{Locality and stratigraphic setting}

The section yielding the crocodile skeleton - referred hereinafter as Crocodile section - is located in one of the most northwesterly quarries on the northern slope of Nagy-Pisznice Hill (Fig. 1, geographic coordinates $47^{\circ} 42^{\prime} 09^{\prime \prime} \mathrm{N}$, $\left.18^{\circ} 29^{\prime} 41^{\prime E} \mathrm{E}\right)$, forming the eastern wall of the quarry. Here, just as in all other quarries on Nagy-Pisznice Hill, quarrying was for the well-bedded, red Pliensbachian Pisznice Limestone and the overlying Törökbükk Limestone, both popular building- and facing-stones ('Gerecse red marble'). In the locality these strata are exposed below the beds of the Crocodile section, in a thickness of ca. $10 \mathrm{~m}$.

The Crocodile section includes the Toarcian Kisgerecse Marl Formation and the lower part of the overlying Tölgyhát Limestone Formation, also belonging to the Toarcian (Fig. 2). The beds of this latter formation form the higher part in the wall of the quarry, but in lack of detailed fossil collecting, the exact age of these higher beds of the Tölgyhát Limestone remained unknown. Some ammonites found in the loose rubble indicate the Aalenian as age for the youngest beds exposed here.
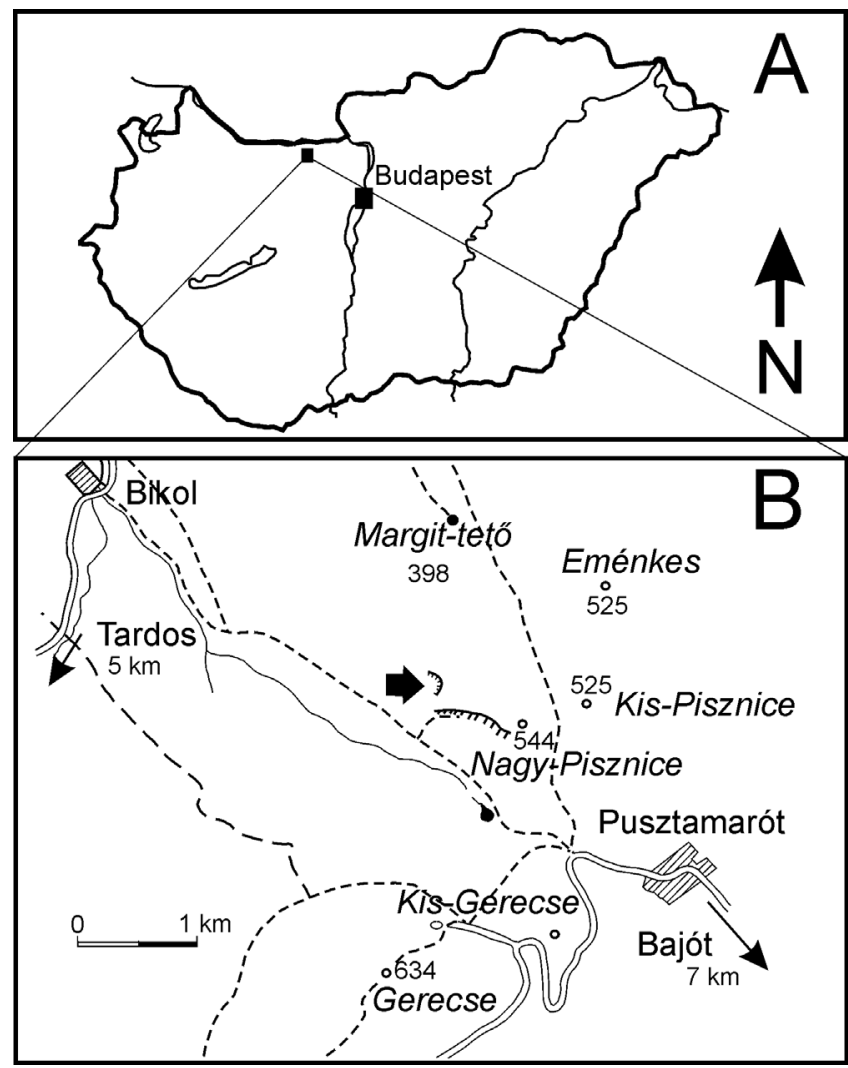

Fig. 1

Location of the Gerecse Mts. (A) and the quarry (solid arrow) with Crocodile section in Nagy-Pisznice Hill area (B) 
Fig. 2

Lithostratigraphy of the Crocodile section (asterisk indicates Bed 13, the layer that yielded the crocodile remains). The three portions represent the three stages of sampling from the strata of the section

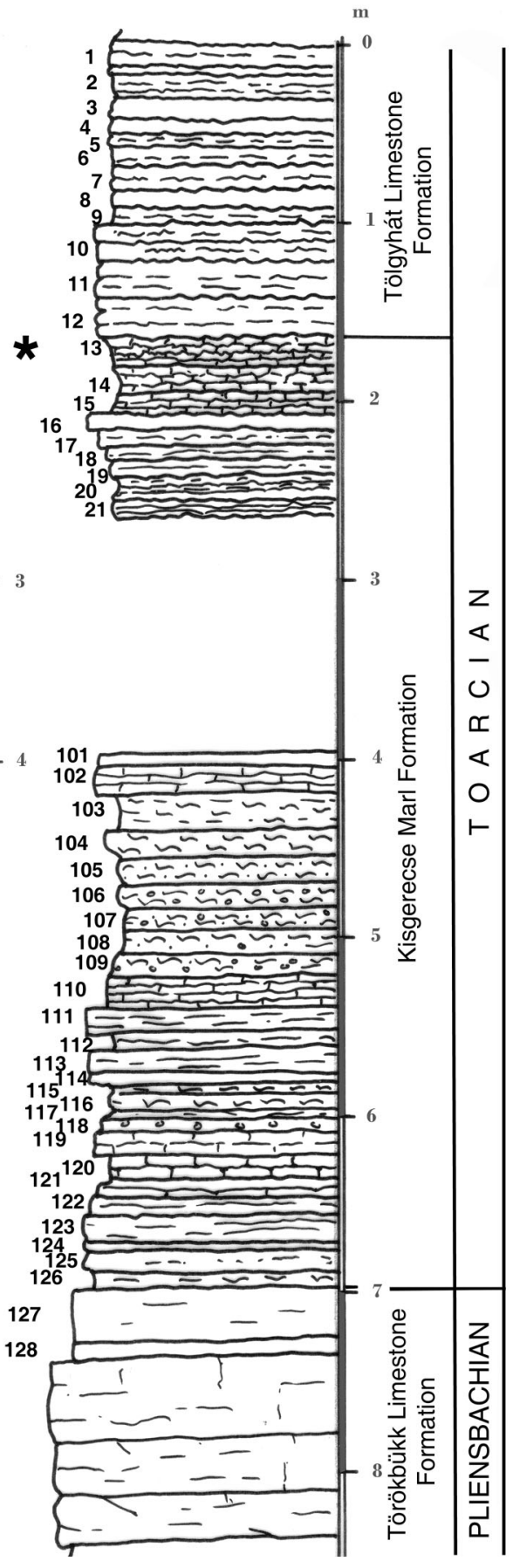

Central European Geology 53, 2010 
The total thickness of the studied beds in the section is $8.4 \mathrm{~m}$. There were 64 numbered beds distinguished while sampling, with $1-2 \mathrm{~m}^{2}$ exposed surfaces. The lowermost two beds (Beds 128 and 127) yielded no diagnostic ammonites. Up to Bed 127 the lithology is red, nodular, clayey limestone. The microfacies of this wackestone-type limestone is characterized by fragments of ammonite shells, tiny ammonites, crinoid ossicles, calcareous foraminifers (e.g. Lenticulina and Spirillina), only one type of arenaceous foraminifer, and a few sponge spicules. These $15-30 \mathrm{~cm}$ thick beds belong to the Törökbükk Limestone containing small nodules with manganese encrustation. From Bed 126 upward the lithology is that of the typical Kisgerecse Marl Formation. The beds gradually become more clayey, with an average thickness of 10-15 cm. Maximum clay content occurs in Beds 110 to 102, while above, up to Bed 13, the beds are of calcareous marl. The texture of the typical Kisgerecse Marl is also wackestone, in which Bositra shell fragments are the most frequent elements. It also contains a few ammonite shell fragments, tiny brachiopods, globochaete, some calcitized radiolarians and small foraminifera. Carbonates are concentrated in nodules surrounded by clay-marl, enriched in iron oxide. From Bed 12 upward the less clayey, nodular limestone belongs to the Tölgyhát Limestone Formation. The typical texture of this limestone is Bositra wackestone to packstone. Further fossil components are tiny ammonites, calcareous foraminifera (Lenticulina, Nodosaria), globochaete and crinoid ossicles. Occasionally there is sharp dissolutional contact between the two textural types. In the type locality the Kisgerecse Marl shows similar tripartite lithology with more calcareous lower and upper parts and a clayey marl portion in between (Konda 1986). The same lithological subdivision could be recognized in the section in the large quarry of Nagy-Pisznice Hill (see Konda 1985).

Ammonites occur in the greatest quantity in the middle, clayey marl, corresponding roughly to the Hildoceras bifrons Zone. A smaller faunal enrichment appeared in the uppermost beds of the Kisgerecse Marl and the lowermost layers of the Tölgyhát Limestone. The preservation of the fossils is poor. All are internal casts with heavily subsolved upper halves. Ammonites are the most common fossils; additional elements include some nautilids, a few belemnite rostra and a single pelagic bivalve specimen. Earlier a single gastropod specimen (Marmorella? sp.) was also reported from the section (Galácz and Szabó 2001).

\section{Biostratigraphic evaluation of the ammonite fauna from the Crocodile section}

The investigation of the Crocodile section is part of the detailed studies on the Upper Liassic - lower Middle Jurassic ammonite faunas of the Gerecse Mountains. These studies were made possible by the extensive field collections carried out by the Hungarian Geological Institute under the guidance of its late director, József Konda, in the years 1976 to 1982. Four localities (Kis-Gerecse, Pisznice, Tölgyhát, Bánya Hill, all in abandoned or working quarries) yielded 
very rich fossil material, some 15,000 specimens (mainly ammonites) collected bed-by-bed from measured sections. The studies of this exceptional material have begun with taxonomical and paleogeographic evaluations of the Toarcian assemblages (Géczy 1984, 1985a, 1985b, 1990). The almost constant dominance of the suborders Phylloceratina and Lytoceratina, as well as the occurrences of several characteristic Ammonitina genera assigned these Toarcian assemblages to the Mediterranean Province, with close affinities to those known from Italy and Greece. Nevertheless, sporadic appearances of zonal indices enabled the application of the detailed Northwest European zonal stratigraphy for these basically Mediterranean ammonite faunal successions.

As the next step of the studies, the faunal revision of the Middle Toarcian of the four sections were worked out (Géczy and Szente 2006), and the Toarcian ammonite assemblages of a previously lesser known section (Kis-Teke Hill, see Galácz and Szabó 2001) was also dealt with (Géczy et al. 2008). The taxonomy of the Upper Toarcian - Aalenian ammonite faunas was also established (Kovács and Géczy 2008; Kovács 2009, 2010). These studies precisely established the composition and stratigraphic distribution of the assemblages and the faunal elements on the basis of recent ammonite stratigraphic syntheses by Elmi et al. (1997); Contini et al. (1997); Rulleau et al. (2001); Venturi and Ferri (2001); Page (2003) and Bécaud et al. (2005), serving as a solid background for the stratigraphic evaluation of the ammonite fauna from the Crocodile section of Pisznice discussed here.

This section exposes a Toarcian succession of five ammonite chronozones (see below). The strata thicknesses of these zones are closely similar to those of given previously as averages for the Gerecse succession (Géczy 1985a), with the sole exception of the much thicker $H$. serpentinum Zone. The bed-by-bed sampling yielded numerous specimens of zonal index species, thus providing an opportunity not only to delineate zones, but, in several cases to distinguish subzones and faunal horizons within them.

\section{Composition of the ammonite fauna}

The beds of the section yielded 624 Ammonitida specimens, of which 314 $(50.3 \%)$ belong to the suborder Ammonitina, 258 (41.3\%) to the Phylloceratina, and $52(8.3 \%)$ to the Lytoceratina. The suborder Ammonitina, appearing mostly in the $H$. serpentinum and $H$. bifrons Zones, loses its dominance upsection, amounting to only one-third of the whole fauna due to the steady increase of Phylloceratina and Lytoceratina species in number (Table 1). This shift in ratio of the Ammonitida suborders follows the tendencies seen in similar data given for the respective faunas from other sections in the Gerecse Mts (Géczy 1985a; Kovács and Géczy 2008). 
Table 1

Proportions of the ammonite suborders in the Crocodile section by zones

\begin{tabular}{|c|c|c|c|}
\hline Zone & Amrnonitina & Phylloceratina & Lytoceratina \\
\hline Speciosum & 34 & 45 & 21 \\
\hline Thouarsense & 33. & 51 & 16 \\
\hline Gradatus & 47. & & 11 \\
\hline Bifrons & 56 & & 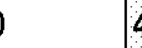 \\
\hline Serpentinum & 51. & & 11 \\
\hline
\end{tabular}

\section{Detailed biostratigraphic subdivision of the Crocodile section}

The following descriptions treat the section by zones, subzones and faunal horizons, wherever possible. The discussions are presented in ascending stratigraphic order (see Fig. 3).

\section{Harpoceras serpentinum Zone}

Lower Toarcian beds were excavated in three of the previously studied sections of the Gerecse Mts (Kis-Gerecse, Pisznice, and Bánya Hill). The detailed studies on the stratigraphy and ammonite faunas were recently taken up again at the Department of Paleontology of the Eötvös L. University. These studies make use of the results of recent studies by Bilotta et al. (2010), and Comas-Rengifo (2010).

The lowermost two beds (127-128, $30 \mathrm{~cm}$ in thickness) did not yield any Ammonitina specimens; thus the presence of the basal Toarcian Dactylioceras tenuicostatum Zone cannot be demonstrated in the section. In the Mediterranean region, in the absence or extreme rarity of the genera Eleganticeras and Harpoceras, the lower boundary of the $H$. serpentinum Zone could be drawn by the appearance of the genus Hildaites, whereas the upper boundary is indicated by the first occurrence of Hildoceras. In the Northwest European region the zone is generally subdivided into two subzones (Eleganticeras elegantulum/E. exaratum and Harpoceras falciferum Subzones) and both into two horizons (E. elagantulum, Harpoceras strangewaysi and Harpoceras pseudoserpentinum, Orthildaites douvillei/H. falciferum, respectively) (Page 2003). However, the ammonite zonation worked out for the Mediterranean region is still being debated due to a lack of definitions of the subzones, and because there is no agreement on the subdivisions into horizons.

In the above-mentioned three sections the presence of the H. serpentinum Zone is demonstrated (Géczy and Szente 2006), and work now under way on the finer subdivision will permit following, with minor modifications, the Submediterranean zonation (Page 2003), mainly based on the relative abundances of 


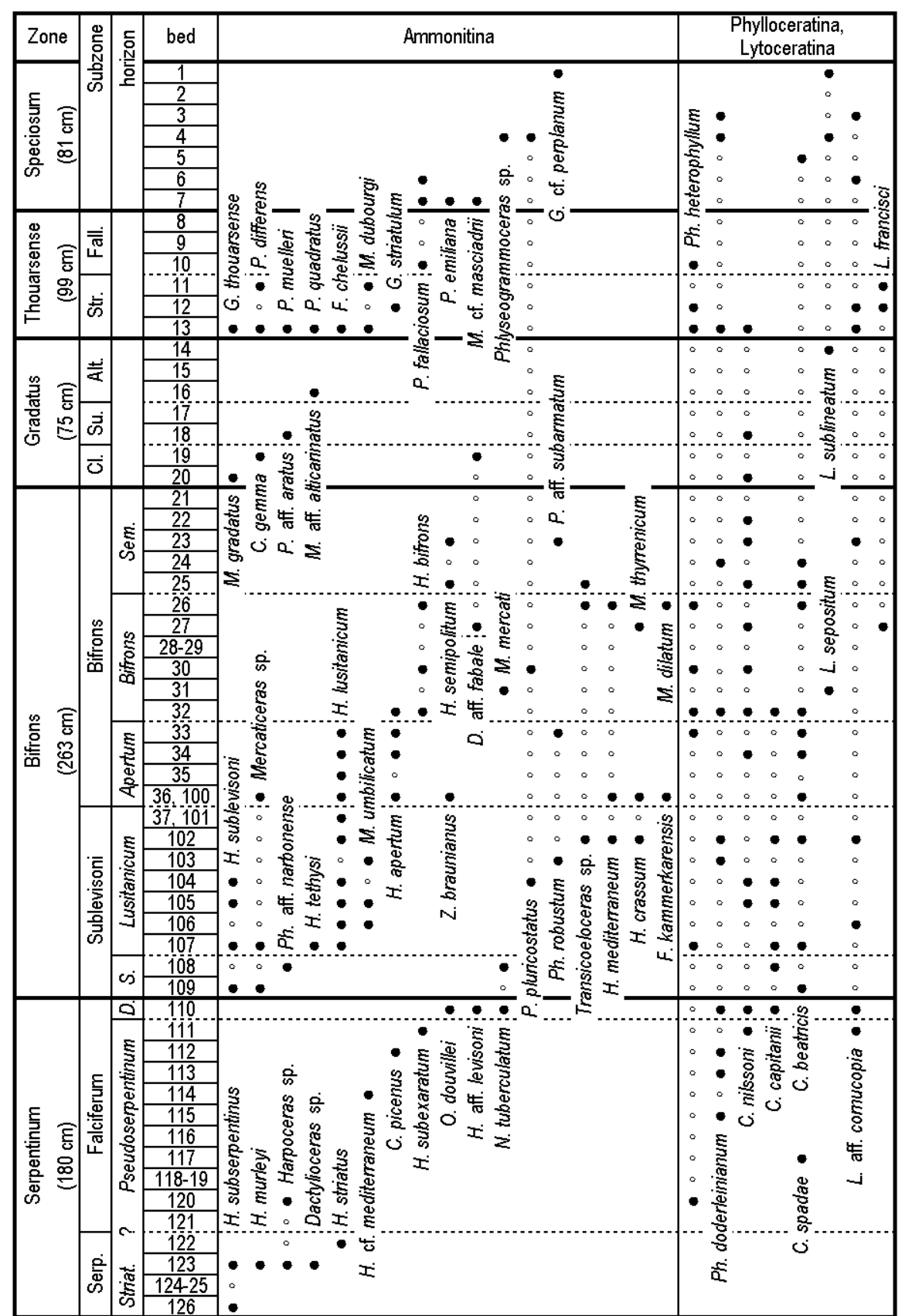

Fig. 3

Stratigraphic subdivisions of the Crocodile section with ranges of the occurring ammonite species (Serp. - Serpentinum, Striat. - Striatulus, D. - Douvillei, S. - Sublevisoni, Sem. - Semipolitum, Cl. Clausus, Su. - Subregale, Alt. - Alticarinatus, Str. - Striatulum, Fall. - Fallaciosum) 
Harpoceras species. In this paper a subdividing of the H. serpentinum Zone into two subzones and three horizons is proposed:

H. serpentinum Subzone (with the Hildaites striatus horizon)

$H$. falciferum Subzone (with the $H$. pseudoserpentinum horizon and the Orthildaites douvillei horizon)

In the Crocodile section the base of the H. serpentinum Zone is at Bed 126, which yielded Hildaites subserpentinus specimens. The other beds belonging to this zone provided ammonites poorer in preservation and which show lower diversity compared to other Gerecse Mts sections. Notable is the almost total absence of Harpoceras and the low number of Hildaites specimens. Consequently, the subdivision of the zone is somewhat uncertain. In the Mediterranean province H. striatus is characteristic for the lower part of the zone (Guex 1973a; Benshili 1989; Bilotta et al. 2010), thus its occurrence in Bed 122 possibly emplaces this and the beds above (121-111, with a single determinable Harpoceras cf. mediterraneum Ammonitina specimen) into the H. pseudoserpentinum horizon of the $H$. falciferum Subzone. The presence of the O. douvillei horizon is unquestionably suggested for Bed 110 by Orthildaites specimens.

The total thickness of beds belonging to this zone is $180 \mathrm{~cm}$. They yielded the following Ammonitina:

Nodicoeloceras tuberculatum Kottek

Dactylioceras sp. indet.

Harpoceras cf. mediterraneum Pinna

Harpoceras subexaratum Bonarelli

Harpoceras sp. indet.

Hildaites striatus Guex (Plate 2, fig. 1)

Hildaites murleyi (Moxon)

Hildaites subserpentinus Buckman (Plate 1, fig. 2)

Hildaites sp. aff. levisoni (Simpson)

Orthildaites douvillei (Haug)

Cingolites picenus Sassaroli et Venturi (Plate 1, figs 1-2).

\section{Hildoceras bifrons Zone}

The subdivision of this zone was based on studies of the Kis-Gerecse, Pisznice and Bánya Hill sections (Géczy and Szente 2006), and on the review of the KisTeke Hill section (Géczy et al. 2008). The mass occurrence and high diversity of the genus Hildoceras permitted identifying the subzones and horizons $(H$. sublevisoni Subzone: $H$. sublevisoni, $H$. tethysi and $H$. lusitanicum horizons; $H$. bifrons Subzone: $H$. apertum, $H$. bifrons and $H$. semipolitum horizons); nevertheless the $H$. tethysi and $H$. lusitanicum, as well as the H. apertum and H. bifrons horizons, could not be distinguished in all sections, because of the different degrees of condensation. In the Crocodile section the beds belonging to the H. bifrons Zone were similarly assigned to the five horizons on the basis of occurrences of index species. 
Hildoceras sublevisoni Subzone: H. sublevisoni, the first representative of the genus Hildoceras, appears in Bed 109; thus the base of the H. bifrons Zone is drawn here. Above the H. sublevisoni horizon (Beds 109-108), two horizon indices (H. tethysi and $H$. lusitanicum) occur together in Bed 107, which makes the unequivocal identification of the $H$. tethysi horizon difficult. The H. lusitanicum horizon extends to Beds 107-101/37, up to the first appearance of H. apertum

$H$. bifrons Subzone: Above the H. apertum horizon (Beds 100/36-33) the $H$. bifrons horizon is represented in the overlying Beds 32-26. The H. semipolitum horizon (beds 25-21) is bracketed between the first $H$. semipolitum and the earliest Merlaites.

From an ammonite stratigraphic point of view it is noteworthy that the $H$. apertum horizon could be clearly distinguished from both the H. lusitanicum and the H. bifrons horizons. These three horizons were identified only in the Kis-Teke Hill section of the above-mentioned, previously studied Gerecse localities (Géczy et al. 2008). The highest specimen number and diversity values are encountered - both for Hildoceras and Mercaticeras - in the H. bifrons Zone of the Crocodile section (i.e. the number of Ammonitina genera is 11 here). However, the fauna shows a decrease in density and diversity upsection from the beds of the $H$. semipolitum horizon.

The total thickness of beds assigned to the $H$. bifrons Zone is $263 \mathrm{~cm}$. These beds yielded the following Ammonitina:

Nodicoeloceras tuberculatum Kottek

Zugodactylites braunianus (d'Orbigny)

Peronoceras sp. aff. subarmatum (Young et Bird)

Transicoeloceras sp. indet.

Harpoceras mediterraneum Pinna (Plate 6, fig. 2)

Polyplectus pluricostatus (Haas)

Hildoceras sublevisoni Fucini

Hildoceras tethysi Géczy

Hildoceras lusitanicum Meister

Hildoceras apertum Gabilly (Plate 5, figs 1-2)

Hildoceras crassum Mitzopoulos

Hildoceras bifrons (Bruguiere)

Hildoceras semipolitum Buckman

Mercaticeras umbilicatum Buckman (Plate 6, figs 1 and 5-6)

Mercaticeras mercati (Hauer) (Plate 5, figs 4-5)

Mercaticeras thyrrenicum (Fucini)

Mercaticeras dilatum (Meneghini)

Frechiella kammerkarensis (Stolley)

Phymatoceras robustum Hyatt

Phymatoceras sp. aff. narbonense Buckman

Denckmannia sp. aff. fabale (Simpson) 
Merlaites gradatus Zone

This is the Mediterranean counterpart of the Haugia variabilis Standard Zone. The detailed infrazonal stratigraphy of this latter zone is based on the Haugia and Pseudolioceras genera so common in the Northwest European region; nevertheless the subdividing of the M. gradatus Zone is far from being generally agreed upon. In the revision of the four previously studied sections in the Gerecse Mts three subzones were distinguished within the zone, without details at horizon level (Géczy and Szente 2006). This is also the case for all the other Mediterranean sections. In spite of the low specimen numbers and diversity in the Crocodile section above the $H$. bifrons Zone, these three subzones were all recorded here as well.

The Merlaites clausus Subzone is usually indicated by the appearance of the genera Crassiceras and Merlaites and the disappearance of the genus Hildoceras. On the basis of the occurrence of Merlaites gradatus and Collina gemma, Beds 20-19 could be assigned to this subzone. The Pseudogrammoceras subregale Subzone (Beds 18-17) could be identified by the appearance of genera Pseudogrammoceras and Podagrosites, while the base of the Merlaites alticarinatus Subzone (beds 16-14) is indicated by the first occurrence of the subzonal index M. alticarinatus.

The total thickness of beds belonging to this zone is $75 \mathrm{~cm}$. The identified Ammonitina species are as follows:

Collina gemma Bonarelli (Plate 6, fig. 4)

Merlaites gradatus (Merla)

Merlaites alticarinatus (Merla)

Podagrosites sp. aff. aratus (Buckman)

Denckmannia sp. aff. fabale (Simpson)

\section{Grammoceras thouarsense Zone}

The ammonite stratigraphy of the Upper Toarcian is different for the Northwest European and the Mediterranean successions. The Mediterranean counterpart of the G. thouarsense Standard Zone is the Geczyceras bonarellii Zone. The standard zone is generally subdivided into four subzones and five horizons (for the somewhat differing zonations see Elmi et al. 1997; Bécaud 2006; Fauré 2007; Metodiev 2008) while in the Mediterranean only two subzones (i.e. of Pseudogrammoceras mediterraneum and P. fallaciosum) are distinguished. While in some studies on Mediterranean successions this twofold subdividing was successfully applied (Elmi et al. 2007; El Hammichi et al. 2009), in other cases even subzones could not be distinguished within the G. bonarellii Zone (Pettinelli et al. 1997). A horizon-level subdividing of the Upper Toarcian beds of the Gerecse sections is in progress. The common occurrence of index species of numerous diagnostic genera (e.g. Pseudogrammoceras, Grammoceras, Podagrosites) allowed a finer stratigraphic subdivision than usual in other Mediterranean successions. On the basis of the Kisgerecse, Pisznice, Tölgyhát and Bánya Hill faunas, a simple 
threefold subdivision of the G. thouarsense Zone was documented: with Pseudogrammoceras bingmanni, Grammoceras striatulum and Pseudogrammoceras fallaciosum Subzones; however, there is no individual section where all these subzones could be demonstrated together.

In the Crocodile section the P. bingmanni Subzone cannot be found. The base of the G. striatulum Subzone (Beds 13-11) is indicated by the appearance of the genus Grammoceras, while the P. fallaciosum Subzone (Beds 10-8) is documented by the index species $P$. fallaciosum.

Bed 13, which yielded the skeletal remains of the crocodile, thus belongs to the G. striatulum Subzone of the Upper Toarcian G. thouarsense Zone, which corresponds to a numeric age of ca. $180 \mathrm{Ma}$ (Ogg 2004).

The total thickness of beds assigned to the G. thouarsense Zone is $99 \mathrm{~cm}$, and yielded the following Ammonitina:

Furloceras chelussii (Parisch et Viale)

Mouterdeiceras dubourgi Elmi et Rulleau (Plate 3, fig. 3, Plate 4, fig. 1)

Pseudogrammoceras differens (Ernst)

Pseudogrammoceras muelleri (Denckmann) (Plate 6, fig. 3)

Pseudogrammoceras fallaciosum (Bayle)

Grammoceras thouarsense (d'Orbigny) (Plate 4, fig. 2)

Grammoceras striatulum (Sowerby) (Plate 2, figs 4-5)

Podagrosites quadratus (Quenstedt) (Plate 2, fig. 1)

\section{Geczyceras speciosum Zone}

This Mediterranean zone corresponds to the Northwest European Hammatoceras insigne (or Phlyseogrammoceras dispansum) Zone. Elmi et al. (1997) and Page (2003) subdivided this zone into two subzones (Geczyceras speciosum and Osperlioceras reynesi Subzones), but horizon level subdivision, for lack of generally acceptable index species, proved elusive. Even the distinguishing of the two subzones is only weakly supported (e.g. Elmi et al. 2007), and in the Mediterranean successions the zone appears as an undivided stratigraphic unit (Parisi et al. 1998; Caracuel et al. 2006; El Hammichi et al. 2009). Due to the absence of the genus Gruneria, the scattered occurrence of the genera Osperlioceras and Phlyseogrammoceras, as well as the strong condensation, no infrazonal subdividing can be established in the Gerecse sections either. For lack of any other index species, the lower boundary of the G. speciosum Zone is identified by the appearance of Pseudolillia, a genus common in Mediterranean areas (see Géczy 1984, 1985a; Kovács and Géczy 2008; Kovács 2009). The upper boundary of the zone is indicated by the appearance of the genus Dumortieria.

The presence of Pseudogrammoceras fallaciosum, together with the lack of Erycitinae species, characterizes the lower part of the G. speciosum Zone. This is where the uppermost beds (7-1) of the section belong. The diversity of the fauna is low. Especially conspicuous is that the subfamily Hammatoceratinae is 
represented by a single specimen only. In the other Gerecse sections this subfamily can be demonstrated from as early as the Merlaites gradatus Zone, commonly represented by $4-5$ species in the lower beds of the $G$. speciosum Zone (Kovács 2009).

The total thickness of beds assigned to the Geczyceras speciosum Zone is $81 \mathrm{~cm}$. These yielded Ammonitina species as follows:

Pseudolillia emiliana (Reynes)

Pseudogrammoceras fallaciosum (Bayle) (Plate 4, fig. 3, Plate 5, fig. 3)

Polyplectus pluricostatus (Haas)

Mouterdeiceras cf. masciadrii (Pelosio)

Geczyceras cf. perplanum (Prinz)

Phlyseogrammoceras sp. indet.

As in all other Gerecse Mts Toarcian sections, phylloceratids and lytoceratids occurred in abundance. The ammonites belonging to these two suborders are paleobiogeographically important but less relevant stratigraphically. The following species were encountered.

Phylloceratina:

Phylloceras heterophyllum (Sowerby) (H. serpentinum - G. speciosum Zone)

Phylloceras doderleinianum (Catullo) (Plate 1, fig. 4) (H. serpentinum - G. speciosum Zone)

Calliphylloceras spadae (Meneghini) (H. serpentinum Zone)

Calliphylloceras mediojurassicum (Prinz) (H. serpentinum - G. thouarsense Zone)

Calliphylloceras nilssoni (Hébert) (H. serpentinum - G. thouarsense Zone)

Calliphylloceras capitanii (Catullo) (H. serpentinum - H. bifrons Zone)

Calliphylloceras beatricis (Bonarelli) (H. bifrons - G. speciosum Zone)

Lytoceratina:

Lytoceras sp. aff. cornucopia (Young et Bird) (H. serpentinum - G. speciosum Zone)

Lytoceras francisci (Oppel) (H. bifrons - G. thouarsense Zone)

Lytoceras sublineatum (Oppel) (M. gradatus - G. speciosum Zone)

Lytoceras (Trachylytoceras) sepositum (Meneghini) (Plate 3, fig. 2) (H. bifrons Zone).

\section{Systematic paleontology}

The following formal descriptions are of species hitherto undocumented from the Gerecse Mts, or important for local stratigraphy or for paleogeography. The illustrated and mentioned specimens are deposited in the collections of the Eötvös Museum of Natural History of Eötvös Loránd University, Budapest.

Phylloceras (Phylloceras) doderleinianum (Catullo 1853)

Plate 1, Fig. 4

1853 Ammonites Doderleinianus, Catullo, p. 19, pl. 1, fig. 3

2010 Phylloceras doderleinianum (Catullo), Venturi et al., p. 126 
Material: 9 specimens in varying states of preservation and 15 fragmentary specimens.

Description: Involute form with wide-oval whorl-section. Narrow umbilicus; convex and smooth flanks; low, broad and rounded venter. Suture-line: short E, relatively wide and asymmetrical L, four auxiliary lobes, diphyllic ES, triphyllic lateral saddles.

Remarks: The revision of the type was carried out by Meneghini (1867-1881); the species differs from Ph. heterophyllum by wider whorls (W/H: 59-66\%), and by low, rounded venter. As the Ph. doderleinianum specimens illustrated in the literature show moderate variability in the width of the whorl-section, similar wide suboval forms with identical stratigraphic range, and suture-lines (marked asymmetrical L lobe), they are considered as synonyms in this paper: Ph. gajarii Prinz, Ph. borni Prinz, Ph. böckhi Prinz, Ph. loczyi Prinz, Ph. mitzopoulosi Negri. The species is a characteristic Mediterranean phylloceratid of the Toarcian.

Distribution: Toarcian: Italy, Greece, Albania, Hungary.

\section{Lytoceras (Trachylytoceras) sepositum Meneghini 1875}

Plate 3, Fig. 2

1875 Lytoceras sepositum, Meneghini, p. 107

1867-1881 Ammonites (Lytoceras) sepositum n. sp., Meneghini, p. 109, pl. 22, figs 3a-b, 4a-b

2001 Lytoceras sepositum Meneghini, Venturi and Ferri, p. 90, fig. h

Material: A single, moderately preserved specimen.

Description: Small, moderately evolute form with subcircular whorl-section. Convex flanks; broad and low venter. Smooth phragmocone with some fine uninterrupted folds on the body chamber. The flared peristome is preceded by a constriction. The suture-line cannot be traced.

Remarks: The species was interpreted as one of the Mediterranean microconch forms of Lytoceras, and was placed in the subgenus Trachylytoceras Buckman by Rulleau (1998). The species is relatively rare; the specimen figured here is the first record from the Gerecse ammonite fauna. Together with L. aff. cornucopia (Young et Bird) it is assigned to the H. bifrons Zone of the Crocodile section.

Distribution: H. serpentinum - H. bifrons Zones: Italy, Spain, France, Greece, Algeria, Hungary, (?) Turkey.

Telodactylites eucosmus (Lippi-Boncambi 1947)

Plate 2, Figs $2-3$

1947 Peronoceras eucosmus Merla in schedis, Lippi-Boncambi, p. 145, pl. 2, fig. 21

2010 Telodactylites eucosmus (Lippi-Boncambi), Venturi et al. p. 262 
Material: One well-preserved specimen.

Description: Evolute, depressed form with wide and deep umbilicus. Oblique and slightly convex flanks, edged shoulder; broad and very low venter. Wide subtrapezoidal whorl-section with maximum thickness at the shoulder. Sharp, dense, fibulate and spined ribbing. Three rectiradiate ribs are looped to long ventrolateral spines, similar to Peronoceras fibulatum (Sowerby). The spines are separated by single ribs rising from the umbilicus and crossing the venter. Four secondaries issue from each spine, are projected forwards, and cross the venter. The suture-line cannot be traced.

Remarks: According to Pinna and Levi-Setti (1971), Peronoceras tuberculatum Pinna 1966 and P. zeissi Géczy 1967 are synonyms of T. eucosmus. The specimen illustrated by Dezi and Ridolfi (1975, p. 43, fig. 116) as T. eucosmus markedly differs from the type by morphology and ornamentation; it probably represents a new species (see Elmi and Benshili 1987, pl. 2, figs 1-2; Bécaud et al. 2005, fig. 3/10-11).

Distribution: M. gradatus (H. variabilis) Zone: Italy, Hungary, France. The exact position of the specimen figured here is unknown, most probably from Bed 6.

\section{Hildaites striatus Guex 1973}

\section{Plate 3, Fig. 1}

1973a Hildaites striatus sp. n., Guex, p. 504, pl. 2, fig. 5, pl. 3, fig. 10, pl. 4, fig. 1, pl. 7, fig. 3, pl. 9, fig. 2 , pl. 10, fig. 2, pl. 14, figs 11, 15, pl. 15, fig. 6 2010 Hildaites striatus Guex, Bilotta et al., fig. 17/A, B

Material: A single, fragmentary specimen.

Description: Evolute form with narrow oval whorl-section. Wide and shallow umbilicus, rounded margin; slightly convex flanks. Narrow, low and carinate venter, bisulcate on the inner whorls. Dense, fine and sinuous ribbing. Sutureline with short and narrow $\mathrm{E}$, wide $\mathrm{L}$, small and straight $\mathrm{U}$ lobes.

Remarks: The species is considered as the Mediterranean counterpart of $H$. wrighti (Spath), from which it differs by bearing denser and finer ribs. The species is typical of the H. striatus horizon (H. serpentinum Subzone) of the Gerecse sections.

Distribution: Lower H. serpentinum (H. levisoni) Zone: Mediterranean Province.

Hildaites subserpentinus Buckman 1921

Plate 1, Fig. 3

1921 Hildaites subserpentinus, Buckman, pl. 217

2006 Hildaites subserpentinus Buckman, Bécaud, p. 80, pl. 35, fig. 2, pl. 37, fig. 1 (cum syn.)

Material: 1 poorly preserved and 3 fragmentary specimens. 
Description: Moderately evolute form with suboval whorl-section. Rounded umbilical wall and margin; slightly convex flanks. Rounded and carinate venter without ventral sulci on the body chamber. Well-developed, somewhat dense, rursiradiate, sinuous ribbing. Suture-line with short E, moderately wide and long L, small U lobes.

Remarks: H. subserpentinus is frequent in the Gerecse assemblages. The species differs from $H$. striatus by more projected and less dense ribs, as well as from $H$. murleyi (Moxon) by a suboval section.

Distribution: H. serpentinum (H. levisoni) Zone: Europe, North Africa.

Cingolites picenus Sassaroli et Venturi 2010

Plate 1, Figs 1-2

2010 Cingolites picenus n. sp., Sassaroli and Venturi, p. 106, text-fig. 6/a-f, i-1, n, pl. 1, figs 5-8, pl. 2, figs $1-5,9$

Material: A single, poorly preserved specimen.

Description: Evolute form with subquadrate whorl-section. Vertical umbilical wall, rounded margin, slightly convex flank. Broad, low and tricarinate-bisulcate venter with wide and deep sulci. The preserved body chamber is about half a whorl long. Simple, rounded, clavate, and slightly rursiradiate ribs with wide, concave intercosta. The ribs gently sigmoid on the last whorl. Hildoceratid suture-line with short E, broad L, small, straight U lobes.

Remarks: The genus was recently introduced by Sassaroli and Venturi (2010) with four species: C. clavatus n. sp., C. picenus n. sp., C. spiralis n. sp. and C. stefaninii (Merla). All are characterized by robust, evolute coiling with strong and clavate ribs. The first three species are typical of the upper Falciferum Subzone in Italian localities, while the last one is known from the H. bifrons Zone of Italy, Greece and Hungary. The specimen figured here agrees well with the holotype of $C$. picenus (Sassaroli and Venturi 2010, pl. 1, fig. 7) in morphology. Its occurrence in the Lower Toarcian Gerecse assemblage confirms the close relationship between the Italian and Hungarian Toarcian ammonite faunas.

Distribution: H. serpentinum Zone (H. falciferum Subzone): Italy.

\section{Hildoceras apertum Gabilly 1976}

Plate 5, Figs 1-2

1976a Hildoceras apertum nov. sp., Gabilly, p. 153, pl. 26, figs 1-6, 9-11

2006 Hildoceras apertum Gabilly, Bécaud, p. 90, pl. 28, fig. 3, pl. 46, figs 1, 3-4 (cum syn.)

Material: One moderately preserved and four fragmentary specimens. 
Description: Evolute, compressed form with rounded subrectangular whorlsection. Shallow umbilicus, rounded margin. The dorsolateral part of the flank is concave, shaping a wide and shallow lateral groove. Rounded shoulder; broad, low and tricarinate-bisulcate venter. Sigmoid ribbing, very weakly developed on the dorsolateral part, while slightly projected on the upper half of the flank. Suture-line with short E, wide L lobes, broad and divided ES and LS.

Remarks: The species is the index of the H. apertum horizon and represents a phylogenetic connection between two closely allied forms: H. lusitanicum Meister and $H$. bifrons (Bruguiére). The former is similar in morphology and ornamentation, but differs from $H$. apertum by the absence of a marked, shallow lateral groove, while the latter is characterized by a wider whorl with a welldeveloped, deeper groove in the middle of the flank.

Distribution: H. bifrons Zone (H. apertum horizon): Europe, (?) Algeria.

\section{Mouterdeiceras dubourgi Elmi et Rulleau 1995 \\ Plate 3, Fig. 3; Plate 4, Fig. 1}

1995 Mouterdeiceras dubourgi n. sp., Elmi and Rulleau, p. 89, text-fig. 1/1-3, 13-14, text-fig. 2/1-2, pl. 10, figs $1-8$, pl. 11, figs 7-8

2007 Mouterdeiceras dubourgi Elmi et Rulleau, Rulleau, p. 78, pl. 33, fig. 1

Material: 3 poorly preserved specimens.

Description: Evolute form with rounded subrectangular whorl-section. Subparallel and slightly convex flanks, rounded shoulder; low and tricarinatebisulcate venter. Strong and rursiradiate ribs rise from the umbilicus, curve forward and become projected on the ventrolateral part. On the penultimate whorl some ribs bifurcate from the margin without any tubercles. The suture-line cannot be traced in all details.

Remarks: The figured specimen agrees well with the holotype (Elmi and Rulleau 1995, pl. 10, figs 1-2). The species resembles Mouterdeiceras masciadrii (Pelosio) in morphology, but differs by bearing rursiradiate ribs. The Phymatoceras tirolense (Hauer) in Géczy (1967, p. 141, pl. 8) from the Bakony Mts differs from Hauer's type (1856, pl. 7, figs 1-2) by the absence of well-developed tubercles. The latter specimen was interpreted as a Mediterranean form of Mouterdeiceras $(\mathrm{Ph}$. tirolense Géczy non Hauer) by Elmi and Rulleau (1995). However, it seems very close to the holotype in all details and is considered as M. dubourgi in this paper.

Distribution: G. thouarsense Zone: France, Hungary. 
Pseudogrammoceras fallaciosum (Bayle 1878)

Plate 4, Fig. 3; Plate 5, Fig. 3

1878 Grammoceras fallaciosum nov. sp., Bayle, pl. 78, figs 1-2

2008 Pseudogrammoceras fallaciosum (Bayle), Seyed-Emami et al., p. 250, fig. 5/N1-3

Material: 4 specimens in varying states of preservation and 3 fragments.

Description: Moderately evolute, compressed form with high elliptical whorlsection. Shallow umbilicus, rounded margin; slightly convex flanks. Narrow, high and carinate venter. Fine, slightly prorsiradiate, sigmoid ribbing. Suture-line with short E, longer and wide L lobes; broad, asymmetrical ES and narrower LS.

Remarks: A significant revision of the taxon was carried out by Gabilly (1976b), who emphasized the variability of the species, and regrouped some taxa as morphotypes of P. fallaciosum: P. cotteswoldiae Buckman, 1889, P. expeditum Buckman 1902, P. subfallaciosum Buckman 1902, P. regale Buckman 1904, and P. pedicum Buckman 1904. This taxonomic interpretation met with acceptance in the literature (Metodiev 2002; Rulleau 2007). The group is frequent in the Gerecse Upper Toarcian, as well as in the Crocodile section, ranging from the upper $G$. thouarsense to the lower G. speciosum Zones.

Distribution: Upper G. thouarsense - lower Ph. dispansum (G. speciosum) Zones, worldwide.

\section{Pseudogrammoceras muelleri (Denckmann 1887)}

Plate 6, Fig. 3

1887 Ammonites (Harpoceras) Muelleri nov. sp., Denckmann, p. 70, pl. 3, fig. 3, pl. 4, fig. 2

2008 Pseudogrammoceras muelleri (Denckmann), Metodiev, fig. 5/n, o

Material: One moderately preserved specimen.

Description: Moderately involute, compressed form with high elliptical whorlsection. Shallow umbilicus, vertical umbilical wall, angled margin. Slightly convex flanks; narrow, rounded and carinate venter. Single, dense, rectiradiate and flexuous ribs, are weakly developed on the lower part of the whorl. Relatively simple suture-line with short E, long and broad L lobes, undivided saddles.

Remarks: The specimen figured here is close to the lectotype (Denckmann, 1887, pl. 4, fig. 2, assigned and re-illustrated by Gabilly (1976b, pl. 27, figs 5-6), and to the specimens in Metodiev (2002, pl. 3, figs 7-8) and Fauré (2007, fig. 7/4, 8). The species differs from other Pseudogrammoceras species by being more involute, and by bearing denser, radial ribs. 
Distribution: H. variabilis - G. thouarsense Zones: Spain. G. thouarsense Zone: France, Bulgaria, Morocco, Algeria. G. thouarsense - H. insigne Zones: Germany. Upper Toarcian: Great Britain, Italy, Portugal, Caucasus.

\section{Grammoceras thouarsense (d'Orbigny 1844)}

Plate 4, Fig. 2

1844 Ammonites thouarsensis, d'Orbigny, p. 222, pl. 57, figs 1-3

2008 Grammoceras thouarsense (d'Orbigny), Metodiev, fig. 5/t

Material: 2 moderately preserved and 2 fragmentary specimens

Description: Evolute, compressed form with suboval whorl-section. Wide and shallow umbilicus; slightly convex flanks; narrow, low, and carinate venter with shallow sulci. Single, rectiradiate, and moderately sinuous ribbing, are less sharp than those of Podagrosites quadratus (Quenstedt). The preserved body chamber of the specimen is about a three-quarter whorl in length. Simple grammoceratid suture-line.

Remarks: The genus is frequent in the Gerecse assemblage, so its presence in this characteristic Mediterranean ammonite fauna permits adopting a restricted Northwest European ammonite zonation for the lower Upper Toarcian.

Distribution: G. thouarsense Zone: Europe, Caucasus, Pamir Mts, Iran. Ph. hillebrandti Zone: North America.

Grammoceras striatulum (Sowerby 1825)

Plate 2, Figs $4-5$

1825 Ammonites striatulus, Sowerby, p. 23, pl. 421, fig. 1

2007 Grammoceras striatulum (Sowerby), Rulleau, p. 84, pl. 42, fig. 2

Material: A single, moderately preserved specimen.

Description: Evolute, compressed form with high elliptical whorl-section. Wide umbilicus, rounded margin; moderately convex flanks. Narrow, rounded and carinate venter. Single, fine, dense and rectiradiate ribs, are more sigmoid than those of $G$. thouarsense.

Remarks: The species is closely allied to G. penestriatulum Buckman, but differs by bearing finer and denser ribs. According to Page (2003), use of G. striatulum as an index for the second subzone of the G. thouarsense Zone has priority over the use of $G$. thouarsense.

Distribution: G. thouarsense Zone: Europe, Caucasus. 
Podagrosites quadratus (Quenstedt 1846)

Plate 2, Fig. 1

1846 Ammonites radians quadratus, Quenstedt, p. 113

2007 Podagrosites quadratum (Quenstedt), Rulleau, p. 84, text-fig. 22/5, pl. 40, fig. 5

Material: One poorly preserved specimen.

Description: Evolute, compressed form with subrectangular whorl-section. Wide and shallow umbilicus; slightly convex flanks; tricarinate-bisulcate venter. Single, rectiradiate, and coarse ribs, curved on the phragmocone, but slightly sigmoid on the body chamber. The suture-line cannot be traced in all details.

Remarks: The genus Podagrosites was assigned by Guex (1973b), type species Pseudogrammoceras podagrosum (Monestier) for Grammoceratinae species, which are characterized by subquadrate whorl-section and broad, carinate and bisulcate venter, including e.g. P. latescens (Simpson). P. quadratus was interpreted as morphotype of $P$. latescens by Gabilly (1976b), from which it differs by narrower whorls. This arrangement is widely accepted in the literature; consequently the range of $P$. quadratus is presumably very similar to that of $P$. latescens. The specimen shown here is close to that figured by Fauré (2002, pl. 17, figs 16-17).

Distribution: G. thouarsense Zone: Europe, Caucasus, Pamir Mts, Iran, North Africa, (?) North America.

\section{Conclusions}

The cephalopod material of the so-called Crocodile section was collected in 1997-1999. The collection resulted in an Ammonoidea fauna of 624 specimens, of which 50.3 percent belong to suborder Ammonitina. The detailed collection work allowed recognition of 5 Toarcian zones, four of them subdivided into subzones and two (i.e. the Harpoceras serpentinum and the Hildoceras bifrons Zone) subdivided into biohorizons. The thickness of the strata representing the ammonite zones, just as the lithological features (i.e. the threefold lithological partition of the Kisgerecse Marl and the appearance of the Tölgyhát Limestone in the Grammoceras thouarsense Zone) agree with the published earlier records. It is demonstrated that the ammonite material, while being basically of Mediterranean affinity, is suitable to follow the standard zonal subdivision applied in the Northwest European region. Thus, the stratigraphic position of the Steneosaurus skeleton discovered here could be assigned to the Grammoceras thouarsense Zone, G. striatulum Subzone, i.e. its absolute age is 180 Ma.

\section{Acknowledgements}

The authors are indebted to Z. Sirányi and A. Fitos for their work in the initial phase of the collecting. I. Szente and I. Főzy helped us in our field work, which 
was carried out within the framework of Project T 016785 of the National Scientific Research Foundation (OTKA). Soledad Ureta (Madrid), Louis Rulleau (Lyon), Federico Venturi (Perugia) and Stefano Sassaroli (Rosora) kindly sent us information helpful for our stratigraphic interpretations. The suggestions and valuable comments of the reviewers (M. Bilotta, J. Guex and J. Pálfy) are highly appreciated.

\section{Explanation of Plates}

Plate 1

Figs 1-2: Cingolites picenus Sassaroli et Venturi. Bed 112. 1: lateral view, 2: ventral view

Fig. 3: Hildaites subserpentinus Buckman. Bed 123. lateral view.

Fig. 4: Phylloceras doderleinianum (Catullo). Bed 106. lateral view.

All figures natural size. Asterisks indicate end of phragmocone.

Plate 2

Fig. 1: Podagrosites quadratus (Quenstedt). Bed 13. lateral view.

Figs 2-3: Telodactylites eucosmus (Lippi-Boncambi). Bed ?6. 2: lateral view, 3: ventral view.

Figs 4-5: Grammoceras striatulum (Sowerby). Bed 12. 4: lateral view, 5: ventral view.

All figures natural size. Asterisks indicate end of phragmocone.

\section{Plate 3}

Fig. 1: Hildaites striatus Guex. Bed 122, lateral view.

Fig. 2: Lytoceras (Trachylytoceras) sepositum (Meneghini). Bed 31, lateral view.

Fig. 3: Mouterdeiceras dubourgi Elmi et Rulleau. Bed 11, lateral view (ventral view on Plate 4, fig. 1).

All figures natural size. Asterisks indicate end of phragmocone.

Plate 4

Fig. 1: Mouterdeiceras dubourgi Elmi et Rulleau. Bed 11, ventral view (lateral view on Plate 3, fig. 3).

Fig. 2: Grammoceras thouarsense (d'Orbigny). Bed 13, lateral view.

Fig. 3: Pseudogrammoceras fallaciosum (Bayle). Bed 6, lateral view.

All figures natural size. Asterisks indicate end of phragmocone.

Plate 5

Figs 1-2: Hildoceras apertum Gabilly. Bed 34, 1: ventral view, 2: lateral view.

Fig. 3: Pseudogrammoceras fallaciosum (Bayle). Bed 7, lateral view.

Figs 4-5: Mercaticeras mercati (Hauer). Bed 31. 4: lateral view, 5: ventral view.

All figures natural size. Asterisks indicate end of phragmocone.

Plate 6

Fig. 1: Mercaticeras umbilicatum Buckman. Bed 106, lateral view.

Fig. 2: Harpoceras mediterraneum Pinna. Bed 100, lateral view.

Fig. 3: Pseudogrammoceras muelleri (Denckmann). Bed 13, lateral view.

Fig. 4: Collina gemma Bonarelli. Bed 19, lateral view.

Figs 5-6: Mercaticeras umbilicatum Buckman. Bed 105, 5: ventral view, 6: lateral view.

All figures natural size. Asterisks indicate end of phragmocone. 
Plate 1
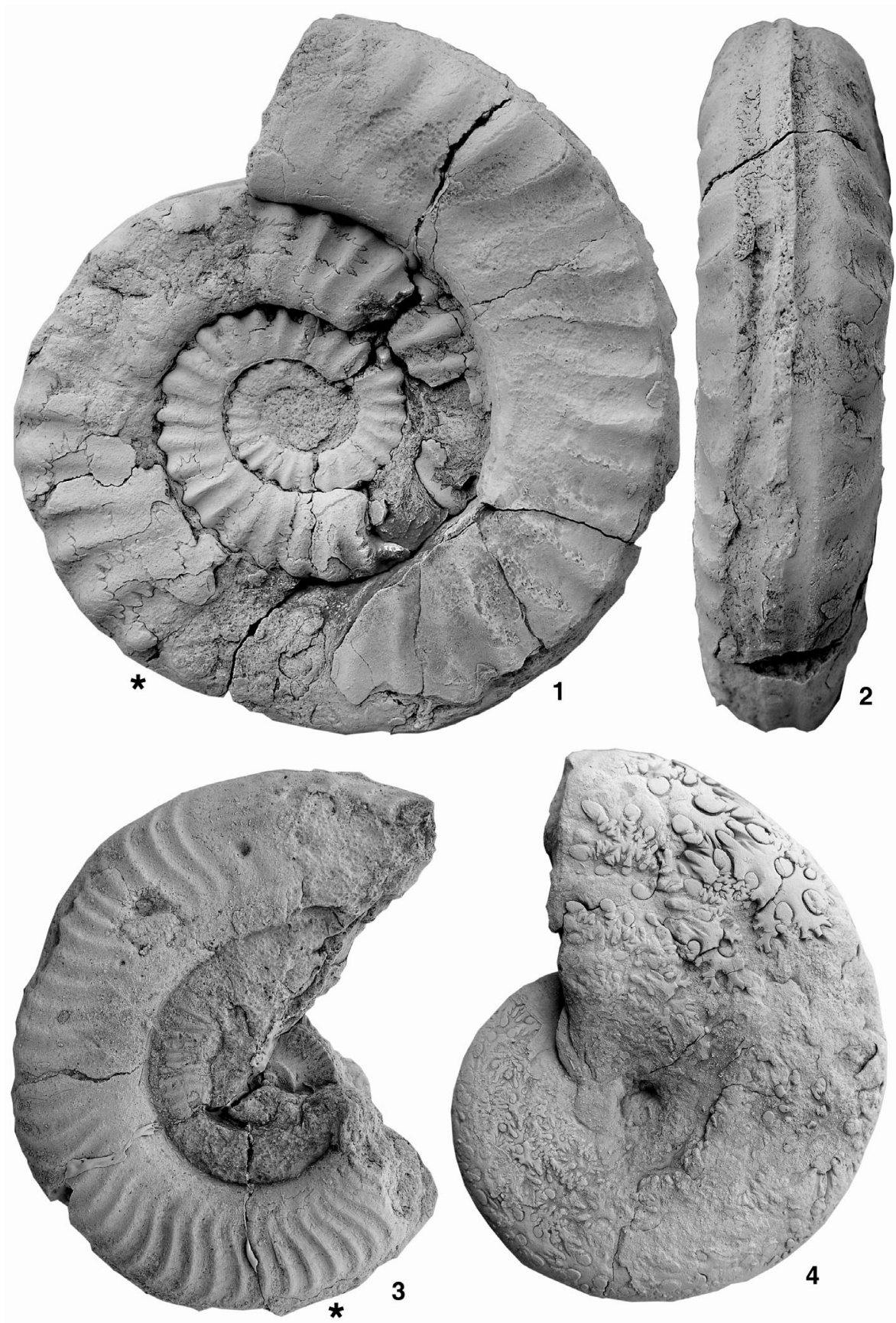

Central European Geology 53, 2010 
334 A. Galácz et al.

Plate 2
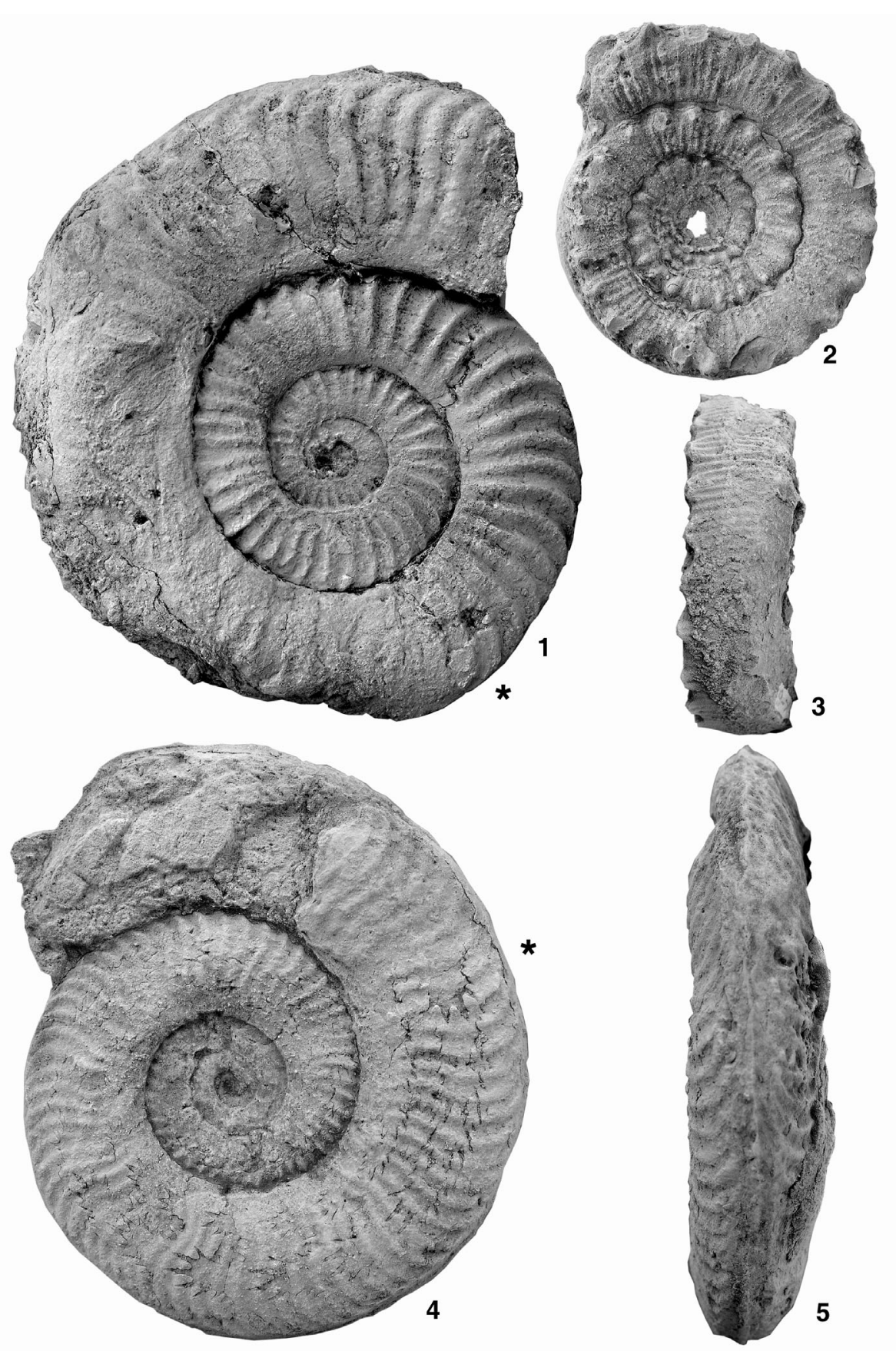

Central European Geology 53, 2010 
Ammonite stratigraphy of a Toarcian section on Nagy-Pisznice Hill (Gerecse Mts, Hungary) 335

Plate 3

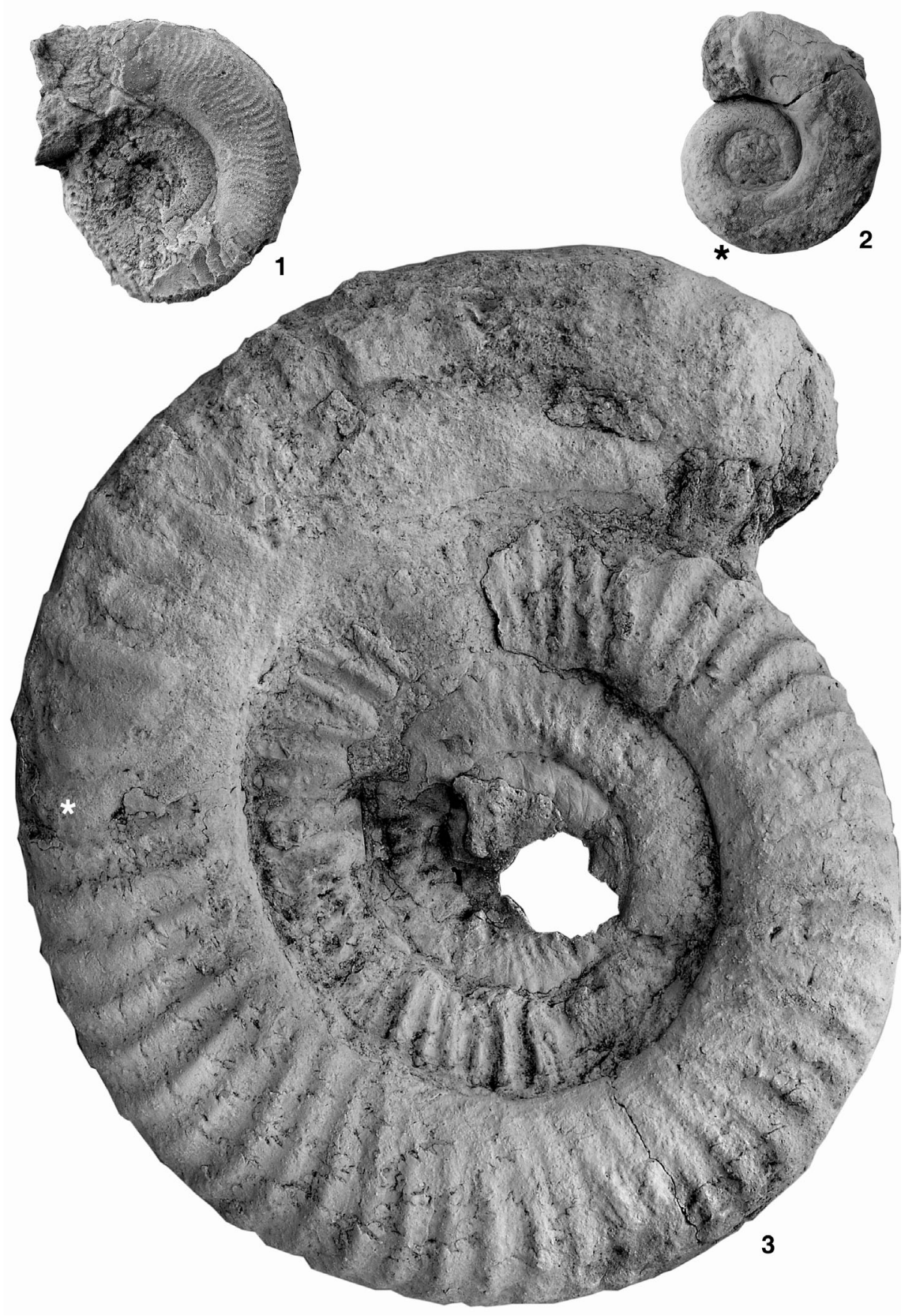

Central European Geology 53, 2010 
336 A. Galácz et al.

Plate 4
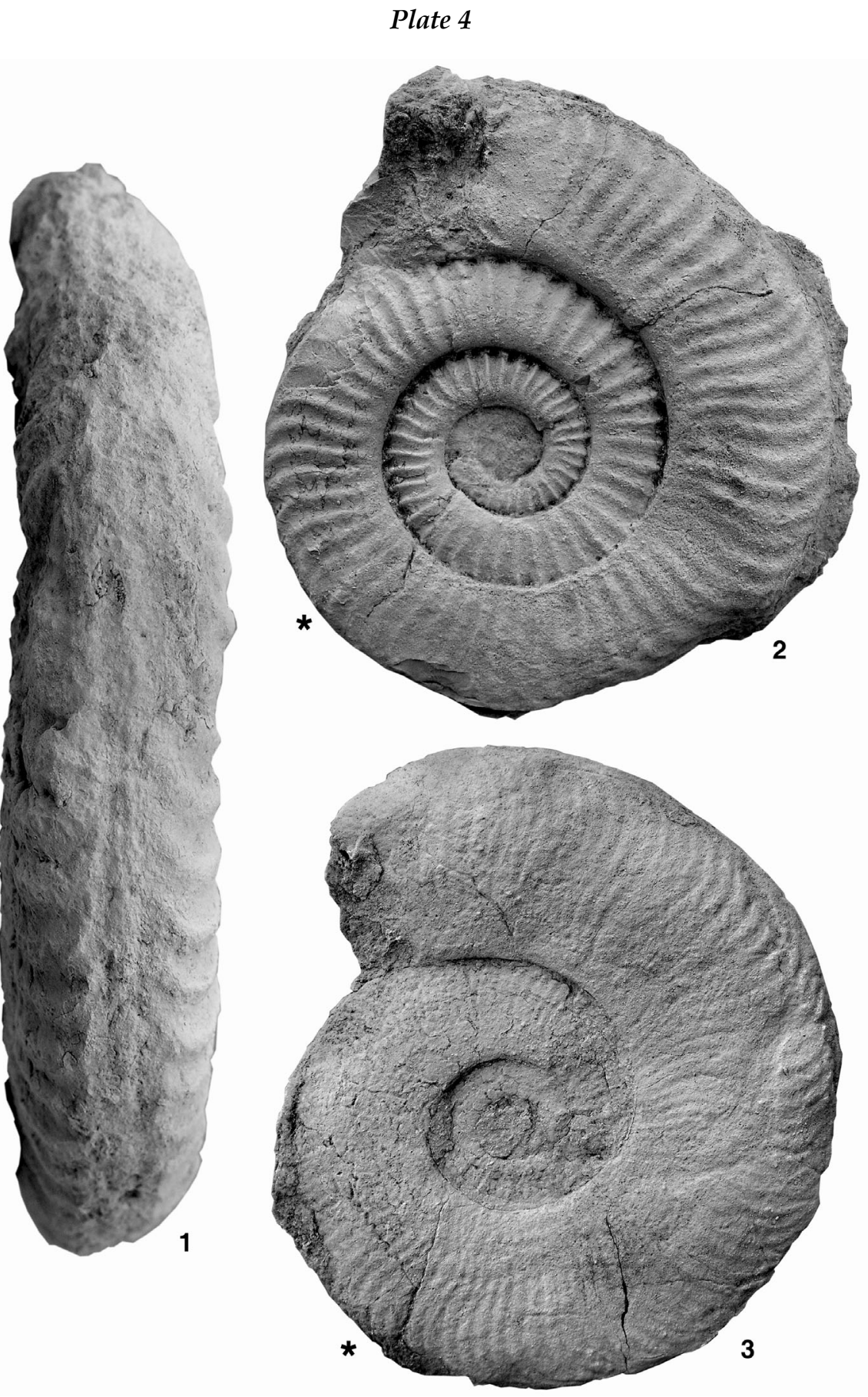

Central European Geology 53, 2010 
Ammonite stratigraphy of a Toarcian section on Nagy-Pisznice Hill (Gerecse Mts, Hungary) 337

Plate 5

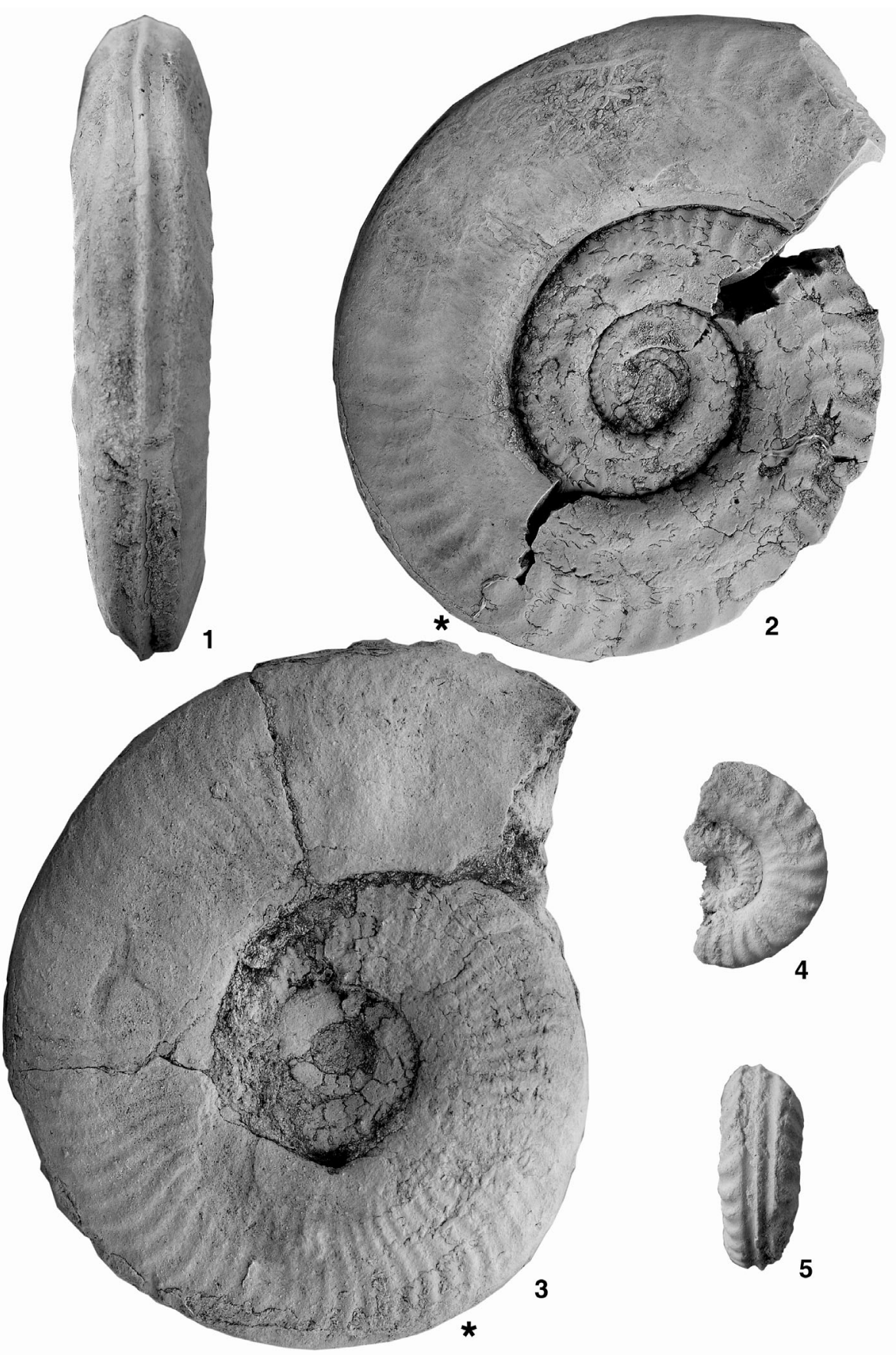

Central European Geology 53, 2010 


\section{Plate 6}
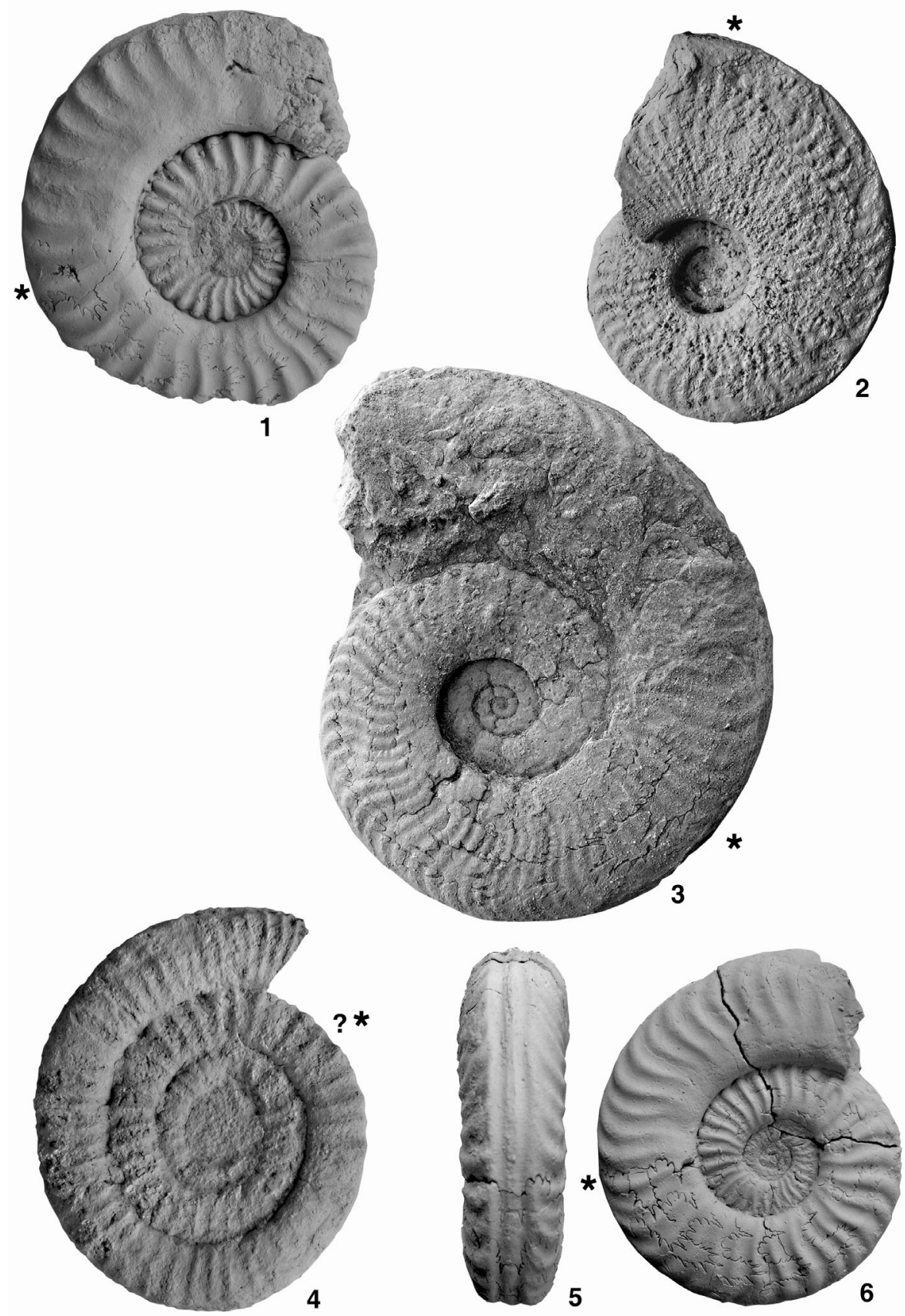

Central European Geology 53, 2010 


\section{References}

Bayle, M. 1878: Fossiles principaux des terrains. - Explication de la Carte Géologique de la France, 4, pls. 168.

Bécaud, M. 2006: Les Harpoceratinae, Hildoceratinae et Paroniceratinae du Toarcien de la Vendée et des Deux-Sèvres (France). - Documents des Laboratoires de Géologie de la Faculté des Sciences de Lyon, 162, pp. 1-245.

Bécaud, M., L. Rulleau, S. Elmi 2005: Le renouvellement des faunes d'ammonites à la limite Toarcien moyen - Toarcien supérieur dans les domaines du nord-ouest de l'Europe et de la Téthys occidentale. - Bulletin de la Société Géologique de France, 176/1, pp. 23-35.

Benshili, K. 1989: Lias-Dogger du Moyen-Atlas Plissé (Maroc), sédimentologie, biostratigraphie et évolution paléogéographique. - Documents des Laboratoires de Géologie de la Faculté des Sciences de Lyon, 106, pp. 1-285.

Bilotta, M., F. Venturi, S. Sassaroli 2010: Ammonite faunas, OAE and the Pliensbachian-Toarcian boundary (Early Jurassic) in the Apennines. - Lethaia, 43/3, pp. 357-380.

Buckman, S.S. 1909-1930: Yorkshire Type Ammonites (1, 2), Type Ammonites (3-7), 790 p., London.

Caracuel, J.E., J. Sandoval, M. Martín-Martín, A. Estévez-Rubio, I. Martín-Rojas 2006: Jurassic biostratigraphy and paleoenvironmental evolution of the Malaguide complex from Sierra Espuna (Internal Betic Zone, SE Spain). - Geobios, 39, pp. 25-42.

Catullo, T.A. 1853: Intorno ad una nuova classificazione delle calcarie rosse ammonitiche delle Alp Venete. - Memorie dell'Imperiale Regio Istituto Veneto di Scienze, Lettere ed Arti, 5, Venezia, p. 57.

Comas-Rengifo, M.J., C. Arias, J.J. Gómez, A. Goy, C. Herrero, M.L. Osete, A. Palencia 2010: A complementary section for the proposed Toarcian (Lower Jurassic) global stratotype: the Almonacid de la Cuba section (Spain). - Stratigraphy and Geological Correlation, 18/2, pp. 133-152.

Contini, D., S. Elmi, R. Mouterde, M. Rioult 1997: Aalénien. - In: Cariou, E., P. Hantzpergue (Eds): Biostratigraphie du Jurassique ouest-européen et méditerranéen. - Bulletin du Centre des Recherches, Elf Explor. Prod. Mém., 17, pp. 37-40.

Császár, G., A. Galácz, A. Vörös 1998: Jurassic of the Gerecse Mountains, Hungary: facies and Alpine analogies. - Földtani Közlöny, 128/2-3, pp. 397-435.

Denckmann, A. 1887: Über geognostischen Verhältnisse der Ungegend von Dörtnen nördlich Goslar, mit besonderer Berücksichtigung der Fauna des oberer Lias. - Abhandlungen zur geologischen Specialkarte von Preussen und den Thüringischen Staaten, 8/2, 108 p.

Dezi, R., S. Ridolfi 1975: Ammoniti Toarciane della "facies non rossa" del Romitorio S. Angelo Presso Cingoli (MC). - Litocompagnucci, pp. 1-48.

El Hammichi, F, K. Benshili, S. Elmi 2009: Les faunes d'Ammonites du Toarcien-Aalénien du Moyen Atlas sud-occidental (Maroc). - Revue de Paléobiologie, 27/2, pp. 429-447.

Elmi, S., K. Benshili 1987: Relations entre les structuracions tectoniques, la composition des peuplements et l'évolution; exemple du Toarcien du Moyen-Atlas méridional (Maroc). Bollettino della Società Paleontologica Italiana, 26/1-2, pp. 47-62.

Elmi, S., R. Mouterde, R. Rocha, L. Rulleau 2007: Une succession de référence pour le Toarcien Moyen et Supérieur: les "Margas calcárias de Sao Giao" dans les environs de Cantanhede sousbassin nord lusitanien, Portugal. - Ciencias da Terra (UNL), 16, pp. 113-133.

Elmi, S., L. Rulleau, J. Gabilly, R. Mouterde 1997: Toarcien. - In: Cariou, E., P. Hantzpergue (Eds): Biostratigraphie du Jurassique ouest-européen et méditerranéen. - Bulletin du Centre des Recherches, Elf Explor. Prod. Mém., 17, pp. 25-36.

Elmi, S., L. Rulleau 1995: Données nouvelles sur la répartition des Phymatoceratinae (Ammonitina, Toarcien). Exemples de convergences et d'évolution itérative. - Hantkeniana, 1, pp. 83-96.

Fauré, Ph. 2002: Le Lias des Pyrénées. - STRATA. Actes du Laboratoire de Géologie Sédimentaire et Paléontologie de l'Université Paul-Sabatier, Série II: Mémoires, 39, 761 p. 
Fauré, Ph. 2007: La Zone a Thouarsense (Toarcien supérieur, Jurassique inferieur) des Corbières (Aude, France) biostratigraphie et évolution sédimentaire. - Bulletin de la Société d'Études Scientifiques de l'Aude, 107, pp. 31-46.

Gabilly, J. 1976a: Le Toarcien a Thouars et dans le centre-ouest de la France. - Les stratotypes français, 3, $217 \mathrm{p}$.

Gabilly, J. 1976b: Évolution et systématique des Phymatoceratinae et des Grammoceratinae (Hildocerataceae, Ammonitina) de la région de Thouars, stratotype du Toarcien. - Mémoires de la Société géologique de France, 54, pp. 1-196.

Galácz, A., J. Szabó 2001: Toarcian gastropods from the Gerecse Mts (Hungary). - Fragmenta Palaeontologica Hungarica, 19, pp. 15-24.

Géczy, B. 1967: Upper Liassic Ammonites from Úrkút, Bakony Mountains, Transdanubia, Hungary. Annales Universitatis Scientiarum Budapestinensis de Rolando Eötvös nominatae, Sectio Geologica, 10, pp. 115-150.

Géczy, B. 1984: Provincialism of Jurassic ammonites, examples from Hungarian faunas. - Acta Geologica Hungarica, 27/3-4, pp. 379-389.

Géczy, B. 1985a: Toarcian ammonite zones in the Gerecse Mountains (Hungary). - Földtani Közlöny, 115/4, pp. 363-368.

Géczy, B. 1985b: Toarcian Ammonite Zones in the Gerecse Mountains, Hungary. - In: Michelsen, O., A. Zeiss (Eds): International Symposium on Jurassic Stratigraphy (Erlangen) I, pp. 218-226.

Géczy, B. 1990: Palaeobiogeographic evaluation of Toarcian Ammonoidea in the Mediterranean and stable European regions. - Általános Földtani Szemle, 25, pp. 231-249. (In Hungarian.)

Géczy, B., Z. Kovács, I. Szente 2008: Remarks on the Toarcian-Aalenian fossil assemblage of the KisTeke Hill, Gerecse Mts (Hungary). - Hantkeniana, 6, pp. 33-55.

Géczy, B., I. Szente 2006: Middle Toarcian Ammonitina from the Gerecse Mts, Hungary. - Acta Geologica Hungarica, 49/3, pp. 223-252.

Guex, J. 1973a: Apercu biostratigraphique sur le Toarcien inférieur du Moyen-Atlas marocain et discussion sur la zonation de ce sous-étage dans les séries méditerranéennes. - Eclogae Geologicae Helvetiae, 66/3, pp. 493-523.

Guex, J. 1973b: Observations sur la répartition biostratigraphique des ammonites du Toarcien supérieur de l'Aveyron (France). - Bulletin des Laboratoires de Géologie, Minéralogie, Géophysique et du Musée géologique de l'Université de Lausanne, 207, pp. 1-14.

Hantken, M. 1872: Die geologischen Verhältnisse des Graner Braunkohlengebietes. - A Magyar Királyi Földtani Intézet Évkönyve, 1, pp. 3-139.

Hauer, R. 1856: Über die Cephalopoden aus dem Lias der Nordöstlichen Alpen. - Denkschriften der k. Akademie der Wissenschaften zu Wien, Math.-Naturhist. 11, pp. 1-86.

Haug, É. 1884: Note sur quelques espèces d'Ammonites nouvelles ou peu connues du Lias supérieur. - Bulletin de la Société géologique de France, 12, pp. 346-356.

Konda, J. 1985: Pisznice Limestone Formation, Nagy-Pisznice Quarry, Lábatlan, Gerecse Mts. Magyarország Geológiai Alapszelvényei. Magyar Állami Földtani Intézet, 6 p. (In Hungarian.)

Konda, J. 1986: Kisgerecse Marl Formation, Kisgerecse Quarry, Süttő, Gerecse Mts. - Magyarország Geológiai Alapszelvényei. Magyar Állami Földtani Intézet, 5 p. (In Hungarian.)

Kovács, Z. 2009: Toarcian-Aalenian Hammatoceratinae (Ammonitina) from the Gerecse Mts (NE Transdanubian Range, Hungary). - Fragmenta Palaeontologica Hungarica, 27, pp. 1-72.

Kovács, Z. 2010: Paroniceratidae (Ammonitina) of the Toarcian from the Gerecse Mts (NE Transdanubian Range, Hungary). - Földtani Közlöny, 140/2, pp. 119-133.

Kovács, Z., B. Géczy 2008: Upper Toarcian-Middle Aalenian (Jurassic) Erycitinae Spath (Ammonitina) from the Gerecse Mts, Hungary. - Hantkeniana, 6, pp. 57-108.

Kulcsár, K. 1913: Geologischen Beobachtungen im Gerecsegebirge. - Földtani Közlöny, 43, pp. 499-502.

Kulcsár, K. 1914: Die mittelliassischen Bildungen des Gerecsegebirges. - Földtani Közlöny, 44, pp. 150-175. 
Liffa, A. 1909: Geologische Notizen aus dem Umgebung von Nyergesújfalu und Neszmély. - A Magyar kir. Földtani Intézet Évi Jelentése 1907-ről, pp. 173-196.

Lippi-Boncambi, C. 1947: Ammoniti del Lias superiore dell'Umbria centrale. - Rivista Italiana di Paleontologia, 53/4, pp. 121-148.

Meneghini, J. 1875: Nuove specie di Phylloceras e di Lytoceras del Liasse superiore d'Italia. - Atti della Società Toscana di Scienze Naturali, 1, pp. 104-109.

Meneghini, J. 1867-1881: Monographie des fossiles du calcaire rouge ammonitique (Lias supérieur) de Lombardie et de l'Apennin Central. - In: Stoppani, A.: Paléontologie Lombarde, 4, pp. 1-242.

Metodiev, L. 2002: Grammoceras, Pseudogrammoceras et Podagrosites (Grammoceratinae, Ammonitina) du Toarcien supérieur dans la région du Balkan (Bulgarie). Taxonomie et biostratigraphie. - Geologica Balcanica, 32/2-4, pp. 165-189.

Metodiev, L. 2008: The Ammonita zones of the Toarcian in Bulgaria - New evidence, subzonation and correlation with the standard zones and subzones in North-Western Europe. - Comptes rendus de l'Académie bulgare des Sciences, 61/1, pp. 87-132.

Ogg, J.G. 2004: The Jurassic Period. - In: Gradstein, F.M., J.G. Ogg, A.G. Smith (Eds): A Geologic Time Scale 2004, Cambridge University Press, pp. 307-343.

d'Orbigny, A. 1842-1851: Paléontologie française, Terrains Jurassique I.: Céphalopodes, V. Masson, Paris, $642 \mathrm{p}$.

Ósi, A., M. Rabi, L. Kordos, A. Fitos 2010: The Gerecse crocodile: the best preserved Steneosaurus (Thalattosauria: Teleosauridae) from the Alpine Lias. - 13. Magyar Őslénytani Vándorgyúlés, 2010. június 3-5, Csákvár. Program, Előadáskivonatok, Kirándulásvezetô. pp. 20-21. (In Hungarian.)

Page, K. N. 2003: The Lower Jurassic of Europe: its subdivision and correlation. - Geological Survey of Denmark and Greenland Bulletin, 1, pp. 23-59.

Parisi, G., A. Baldanza, L. Benedetti, E. Mattioli, F. Venturi, S. Cresta 1998: Toarcian stratigraphy of the Colle d'Orlando section (Umbria, Central Italy, northern Apennine). - Bollettino della Società Paleontologica Italiana, 37/1, pp. 3-39.

Pettinelli, R., M. Nocchi, G. Parisi 1997: Late Pliensbachian-Toarcian biostratigraphy and environmental interpretations in the Ionian Basin (Lefkas Island, Western Greece) as compared to the Umbria-Marchean Basin (Central Italy). - Bollettino del Servizio Geologico d'Italia, 114, pp. $97-158$.

Pinna, G., F. Levi-Setti 1971: I Dactylioceratidae della provincia Mediterranea (Cephalopoda-Ammonoidea) - Memorie della Società Italiana di Scienze Naturali, 19, pp. 49-136.

Prinz, Gy. 1906a: Neue Beiträge zur Kentniss der Gattung Frechiella. - Földtani Közlöny, 36/1-3, pp. 155-160.

Prinz, Gy. 1906b: Dumortieren von Piszke. - Földtani Közlöny, 36/1-3, pp. 161-162.

Quenstedt, F.A. 1846-1849: Petrefactenkunde Deutschland. I. Die Cephalopoden. Fues, Tübingen, $580 \mathrm{p}$.

Rulleau, L. 1998: Évolution et systématique des Phylloceratidae et des Lytoceratidae du Toarcien et du Dogger inférieur de la région lyonnaise. - Documents des Laboratoires de Géologie de la Faculté des Sciences de Lyon, 149, pp. 1-167.

Rulleau, L. 2007: Biostratigraphie et Paleontologie du Lias superieur et du Dogger de la region lyonnaise, Tome 1. - Section Géologie et Paléontologie du Comité d'Enterprise Lafarge Ciments, $382 \mathrm{p}$.

Rulleau, L., S. Elmi, B. Thévenard 2001: Géologie et Paléontologie des dépots ferrugineux du Toarcien et de l'Aalénien aux environs de Lyon. - Documents des Laboratoires de Géologie de la Faculté des Sciences de Lyon, 154, pp. 1-153.

Sassaroli, S., F. Venturi 2010: Cingolites n. gen., a new lower Toarcian Hildoceratinae (Ammonitina) from the Marchean Apennines (Cingoli, Macerata, Italy). - Bollettino della Società Paleontologica Italiana, 49/2, pp. 97-118. 
Seyed-Emami, K., FT. Furisch, M. Wilmsen, M.R. Majidifard, A. Shekarifard 2008: Lower and Middle Jurassic ammonoids of the Shemshak Group in Alborz, Iran and their palaeobiogeographical and biostratigraphical importance. - Acta Palaeontologica Polonica, 53/2, pp. 237-260.

Sowerby, J. 1825: The Mineral Conchology of Great Britain. - Vol. 5, London, pp. 486-503.

Staff, H. 1906: Beiträge zur Stratigraphie und Tektonik des Gerecsegebirges. - A Magyar kir. Földtani Intézet Évkönyve, 15, pp. 194-204.

Venturi, F, R. Ferri 2001: Ammoniti Liassici dell'Appennino Centrale. - Tibergraph, Citta di Castello, $268 \mathrm{p}$.

Venturi, F, G. Rea, G. Silvestrini, M. Bilotta 2010: Ammonites. A geological journey around the Apennine Mountains. - Porzi, Perugia, $367 \mathrm{p}$.

Vigh, G. 1969: Explanation of the 10,000 geological map of the Dorog basin. Pusztamarót. Geological Institute of Hungary. pp. 1-69. (In Hungarian.)

Vigh, Gy. 1925: Geologische Notizen aus dem Gerecsegebirge. - A M. kir. Földtani Intézet Évi Jelentése az 1920-23 évekről, pp. 91-98.

Vigh, J. 1927: Paroniceraten aus dem ungarischen oberen Lias, nebst pathologischen Ammonitenformen. - Földtani Közlöny, 57/10-12, pp. 248-261.

Vigh, J. 1940: Stratigraphische und tektonische Beobachtungen in der Umgebung des Berges Nagypisznice. - A M. kir. Földtani Intézet Évi Jelentései az 1933-35 évekről, pp. 1467-1478. 